\title{
Challenges of assessing cetacean population recovery and conservation status
}

\author{
Milton M. R. Freeman* \\ Canadian Circumpolar Institute, University of Alberta, Edmonton, Alberta T6G 2E1, Canada
}

\begin{abstract}
This paper examines the extent to which depleted whale populations have recovered (or not) and their perceived current conservation status and prognosis for continued survival, as represented in the International Union for Conservation of Nature and Natural Resources (IUCN) Red Lists. It is concluded that current hypothetical and untested predictions of extinction risk, while in many cases drawing attention to justifiable conservation needs, may seriously undervalue the resilience of species that have evolved to live in a dynamic and ever-changing reality including centuries of heavy exploitation by humankind. The paper questions the appropriateness of Red Listing criteria for long-lived highly mobile ocean-dwelling species that are scarcely affected by the principal threats upon terrestrial or aquatic species living in relatively restricted areas subject to habitat fragmentation and/or loss. This analysis draws attention to the problems associated with objectively assessing the conservation status of charismatic species and the value conflicts that may override evidence-based scientific conservation assessments.
\end{abstract}

KEY WORDS: Whales - Whaling · Conservation · Population recovery $\cdot$ Predicting extinction Red Listing $\cdot$ Charismatic species

\section{INTRODUCTION}

The history of whaling provides one of the bestknown examples of human over-exploitation of living resources. However, no whale species has become extinct in historic or modern times, despite the pressures of whaling over many centuries, although uncertainty exists as to whether pre-modern whaling in the 17th century contributed to the extinction of the North Atlantic gray whale (Gerber et al. 2000, Clapham \& Link 2006). It was only in 2007 that the first known human-caused extinction of a cetacean species is believed to have occurred, when the last few individuals of the world's rarest mammal species, the Yangtze river dolphin Lipotes vexillifer, appear to have finally succumbed to boat collisions, dam construction, pollution and bycatch in local fisheries (Turvey et al. 2007). There are examples of severely depleted populations of some widely distributed whale species, including the west Pacific population of the gray whale Eschrichtius robustus and the Spitsbergen population of the bowhead whale Balaena mysticetus; both are believed to number in the tens or low hundreds at this time. There are also dolphin populations whose principal or exclusive range is in rivers, or in coastal or nearshore areas where fishery bycatch and boat traffic are causes of high mortality/injury. Thus, there is a far greater risk of extirpation or extinction than is likely to exist for wide-ranging cetacean populations. Many whale species are wide-ranging, with populations numbering in the tens or hundreds of thousands, and their habitat is expansive and non-fragmented; however, some of these species are shown on the International Union for Conservation of Nature and Natural Resources (IUCN) Red List as being in serious danger of extinction.

The 1991 IUCN Red List provides a benchmark to assess changes in cetacean conservation status at later points in time, although the listing criteria and membership in the Cetacean Specialist Group also changes over time. In the 1991 Red List (Klinowska 1991), 5 species are listed as Endangered, 7 as Vulnerable, 1 as 
Indeterminate, and 65 as Insufficiently Known. New listing criteria were introduced in 1994, and a reassessment by the Cetacean Specialist Group using these criteria listed 2 species as Critically Endangered, 6 as Endangered, 6 as Vulnerable, 1 as Near Threatened, 14 as Lower Risk/Conservation Dependent, 33 as Data Deficient (an equivalent category to the 'Indeterminate' in the 1991 assessments), and 13 as Lower Risk/Least Concern (and not included in the 1991 listing; see Table 1).

The 1996 list, for the first time also assessed 16 subspecies and geographical cetacean populations, with 7 of these categorized as Endangered, 5 as Vulnerable, 3 as Lower Risk/Conservation Dependent and 1 as Data Deficient. In many of these listings, reliable population numbers do not exist, and none are mentioned in the Cetacean Specialist Group Report (IUCN 2007a), where principal importance in several cases is placed on the large numbers of removals during the industrial whaling era, the slow rate of recovery of some populations, and known or projected environmental threats.

\section{RELIABILITY OF WHALE CONSERVATION ASSESSMENTS}

The current (2007) Red List of cetaceans identifies 15 species as in danger of extinction in the near future (i.e. listed as Critically Endangered, Endangered or Vulnerable). These endangered cetaceans include several riverine or inshore species, some with populations in the low hundreds, together with other more widely distributed or ubiquitous cetacean species having much larger populations (Table 2). Many cetacean population estimates remain uncertain, an example being the sperm whale Physeter macrocephalus, whose population estimates in the literature vary from 350000 (American Cetacean Society, www.acsonline. org/factpack/index.html) to ca. 2000000 (www. 70south.com/information/antarctic-animals/whales). The sperm whale appears on the Red List as Vulner-

Table 1. The Red List classification of cetaceans in 1991 and 2007

\begin{tabular}{|llll|}
\hline Classification & 1991 & 2007 & Notes \\
\hline Critically Endangered & - & 2 & CR not used in 1991 \\
(CR) & & & \\
Endangered (EN) & 5 & 6 & \\
Vulnerable (VU) & 7 & 6 & \\
Lower Risk (LR) & - & 28 & LR not used in 1991 \\
Insufficiently Known (K)/ & 65 & 33 & K and DD are the same \\
$\begin{array}{llll}\text { Data Deficient (DD) } \\
\text { Unlisted (U) }\end{array}$ & 1 & - & U not currently used \\
Indeterminate (I) & 1 & - & I not currently used \\
& & & \\
\hline
\end{tabular}

able (IUCN 2007b), that is 'facing a high risk of extinction in the wild' (IUCN 2007c). The sperm whale is a long-lived, wide-ranging species occurring in every ocean and the territorial waters of more than 40 countries from the equatorial to polar regions, yet its classification as Vulnerable A1 bd is almost identical to that of the Amazon river dolphin Inia geoffrensis, listed as Vulnerable A1cd. Table 3 presents a summary of the factors used to produce these 2 almost identical Red Listings. Furthermore, the Amazon river dolphin has 3 distinct subspecies, each of unknown population numbers but thought to collectively total a few thousand individuals living in a polluted and fragmented habitat (with future habitat degradation from mining and damming, and fishery impacts believed certain to intensify). The challenging environmental situation and the relatively small and unknown population of river dolphins seems to justify a listing as Vulnerable; if so, the sperm whale, in comparison, seems much less 'threatened with extinction'. Similarly questionable listings occur with other formerly heavily exploited whales, e.g. the common minke whale Balaenoptera acutorostrata, the Antarctic minke whale $B$. bonaerensis - 'which may be the most abundant baleen whale species today' according to the Red List account (IUCN $2007 d$ ) - and the sei whale $B$. borealis. Table 4 provides further information on these 4 abundant and wide-ranging oceanic species taken from the IUCN Red List assessments.

It is significant that the posited major past, present and future threats to each of these 4 abundant species are related to their use for food, scientific, cultural and leisure activities, their use in trade, and their vulnerability to fishery-related accidental mortality. As will be discussed below, the current and probable future threat from whale fisheries is in reality very small at present, and has little realistic chance of expanding in the future. In the case of the Antarctic minke whale, the current population is believed to range from 510000 to 1.14 million (www.iwcoffice.org/conservation/estimate.htm) or from 610000 to 1.28 million today (www.70south.com/information/ antarctic-animals/ whales). The Red List cites the removal of 98202 Antarctic minke whales taken during the $1956 / 57$ to $1986 / 87$ whaling seasons as significant. However, assuming a population of 500000 minke whales at that time and a reasonably constant annual rate of removals, that level of harvest (98 202 divided by $30 \mathrm{yr}=3274$ ) would have represented an annual $0.7 \%$ rate of removal-a sustainable rate, allowing the population to continue growing at $>2 \%$ each year. If 500000 is too large 
Table 2. Red List of endangered cetaceans (2007). For classification abbreviations see Table 1

\begin{tabular}{|c|c|c|c|c|}
\hline Species & Classification & Occurrence & Population estimate & Source \\
\hline $\begin{array}{l}\text { Vaquita } \\
\text { Phocoena sinus }\end{array}$ & $\mathrm{CR}$ & Local, riverine & $<1000$ & $W W F^{a}$ \\
\hline $\begin{array}{l}\text { Yangtze river dolphin } \\
\text { Lipotes vexillifer }\end{array}$ & $\mathrm{CR}$ & Local, riverine & $<100$ & $W W W F^{a}$ \\
\hline $\begin{array}{l}\text { Indus river dolphin } \\
\text { Planista minor }\end{array}$ & EN & Local, riverine & ca. 1000 & Martin (1990) \\
\hline $\begin{array}{l}\text { Ganges river dolphin } \\
\text { Planista gangetica }\end{array}$ & EN & Local, riverine & $<2000$ & $W W W F^{a}$ \\
\hline $\begin{array}{l}\text { Hector's dolphin } \\
\text { Cephalorhynchus hectori }\end{array}$ & EN & NZ coastal waters & са. 7400 & $W W W F^{a}$ \\
\hline $\begin{array}{l}\text { Amazon river dolphin } \\
\text { Inia geoffrensis }\end{array}$ & EN & Local, riverine & Low-10s of thousands & $\mathrm{IUCN}^{\mathrm{b}}$ \\
\hline $\begin{array}{l}\text { Harbour porpoise } \\
\text { Phocoena phocoena }\end{array}$ & VU & Wide-ranging coastal & $>600000$ & $\mathrm{IUCN}^{\mathrm{b}}$ \\
\hline $\begin{array}{l}\text { Beluga } \\
\text { Delphinapterus leucas }\end{array}$ & VU & Wide ranging coastal & $>200000$ & $\mathrm{ACS}^{\mathrm{c}}$ \\
\hline $\begin{array}{l}\text { N. Pacific right whale } \\
\text { Eubalaena japonica }\end{array}$ & EN & Localized, coastal & ca. 150 & $\mathrm{ACS}^{\mathrm{c}}$ \\
\hline $\begin{array}{l}\text { N. Atlantic right whale } \\
\text { Eubalaena glacialis }\end{array}$ & EN & Localized, coastal & ca. 350 & $W W F^{a}$ \\
\hline $\begin{array}{l}\text { Blue whale } \\
\text { Balaenoptera musculus }\end{array}$ & EN & Wide-ranging, oceanic & $\begin{array}{l}\text { N. Atlantic: } 32200 \\
\text { US west coast: } 1900 \\
\text { S. Indian Ocean: } 5000 \\
\text { S. Hemisphere: } 1260\end{array}$ & $\begin{array}{l}\text { IWC }^{\mathrm{d}} \\
\text { Gerber et al. (2000) } \\
\text { Gerber et al. (2000) } \\
\text { Gerber et al. (2000) }\end{array}$ \\
\hline $\begin{array}{l}\text { Fin whale } \\
\text { Balaenoptera physalus }\end{array}$ & EN & Wide-ranging, oceanic & $\begin{array}{l}\text { N. Hemisphere: } 40000 \\
\text { S. Hemisphere: } 85000\end{array}$ & $\begin{array}{l}\mathrm{ACS}^{\mathrm{c}} \\
\text { Gerber et al. (2000) }\end{array}$ \\
\hline $\begin{array}{l}\text { Sei whale } \\
\text { Balaenoptera borealis }\end{array}$ & EN & Wide-ranging, oceanic & $\begin{array}{l}\text { N. Atlantic: ca. } 10000 \\
\text { N. Pacific: } 22000-37000 \\
\text { S. hemisphere: } 24000\end{array}$ & $\begin{array}{l}W W F^{a} \\
W W F^{a} \\
W W F^{a}\end{array}$ \\
\hline $\begin{array}{l}\text { Sperm whale } \\
\text { Physeter macrocephalus }\end{array}$ & VU & Wide-ranging, oceanic & 200000 - 1.5 million & $\mathrm{NMFS}^{\mathrm{e}}$ \\
\hline $\begin{array}{l}\text { Humpback whale } \\
\text { Megaptera novaengliae }\end{array}$ & VU & $\begin{array}{l}\text { Wide-ranging, } \\
\text { coastal - offshore }\end{array}$ & $\begin{array}{l}\text { N. Atlantic: } 10600 \\
\text { N. Pacific: } 6000-8000 \\
\text { S. Hemisphere: } 17000\end{array}$ & $\begin{array}{l}\text { Gerber et al. (2000) } \\
\text { Gerber et al. (2000) } \\
\text { Gerber et al. (2000) }\end{array}$ \\
\hline \multicolumn{5}{|c|}{$\begin{array}{l}\text { adWorld Wildlife Fund: www.panda.org/about_wwf/what_we_do/species/about_species/species_factsheets/ } \\
\text { bInternational Union for Conservation of Nature and Natural Resources: www.iucnredlist.org/search-basic } \\
{ }^{c} \text { American Cetacean Society: www.acsonline.org/factpack/ } \\
\text { dInternational Whaling Commission: www.iwcoffice.org/conservation/estimate.htm } \\
\text { e National Marine Fisheries Service: www.nmfs.noaa.gov/pr/species/mammals/cetaceans/spermwhale.htm }\end{array}$} \\
\hline
\end{tabular}

an assumed population level for 1956/57, the level of offtake was evidently still sustainable as demonstrated by that $1956 / 57$ population increasing to the current higher population level.

Among the questions that should be asked in regard to whale conservation (and which should likely be kept in mind when considering Red Listing) are the following: (1) Can depleted whale stocks recover in the medium-term future? (2) How do we assess whether conservation goals are achieved? (3) How can we ensure that stocks are safeguarded against biologically-significant depletion? These are important policy-relevant questions, given the high cost of ensuring ongoing whale monitoring and protection, and an always existing need to deploy resources to protect truly threatened or endangered species (Brownell et al. 1989, Tyack 1989, Gerber et al. 2000).

\section{RECOVERY FROM HISTORIC OVER-EXPLOITATION}

On biological grounds, it might appear that whales are inherently vulnerable because, although many of the larger species are long-lived (e.g. bowheads live for more than $200 \mathrm{yr}$ ), some species require $10 \mathrm{yr}$ to 
Table 3. Comparison of the similar Red List classification of 2 cetaceans

\begin{tabular}{|c|c|}
\hline $\begin{array}{l}\text { Amazon river dolphin } \\
\text { Inia geoffrensis }\end{array}$ & $\begin{array}{c}\text { Sperm whale } \\
\text { Physeter marcocephalus }\end{array}$ \\
\hline Red List Category: VU A1cd & Red List category: VU A1bd \\
\hline Population in 10 s of thousands & Population in 100 s of thousands \\
\hline Distributed in 2 river basins in NE South America & $\begin{array}{l}\text { Distributed through tropical, temperate and sub-polar } \\
\text { oceans in both hemispheres }\end{array}$ \\
\hline Habitat fragmentation (dams) and more being proposed & No habitat fragmentation occurring or likely to occur \\
\hline $\begin{array}{l}\text { Mining pervasive, if not rampant, contamination } \\
\text { a concern (including mercury) }\end{array}$ & $\begin{array}{l}\text { Not immediately threatened, but some regional } \\
\text { populations require close evaluation and monitoring }\end{array}$ \\
\hline Fishermen sometimes kill and maim the dolphins & $\begin{array}{l}\text { Whaling by one Indonesian village and N. Pacific research } \\
\text { whaling together remove ca. } 20 \text { to } 25 \text { whales annually }\end{array}$ \\
\hline $\begin{array}{l}\text { Growing human population along the rivers, conflicts } \\
\text { certain to intensify }\end{array}$ & $\begin{array}{l}\text { Indonesia traditional whaling and research whaling } \\
\text { unlikely to increase offtake. Ship strikes, net } \\
\text { entanglements occur fairly often }\end{array}$ \\
\hline $\begin{array}{l}\text { Major threats listed as: } \\
\text { habitat degradation and loss; } \\
\text { fishing-related mortalities; pollution } \\
\text { affecting habitat and food }\end{array}$ & $\begin{array}{l}\text { Major threats listed as: } \\
\text { harvesting, international trade in the past; } \\
\text { fishery-related mortalities; poor recruitment, } \\
\text { reproduction (present and future); other intrinsic } \\
\text { factors (present and future) }\end{array}$ \\
\hline Source: www.iucnredlist.org/search/details.php/10831/all & Source: www.iucnredlist.org/search/details.php/41755/all \\
\hline
\end{tabular}

reach sexual maturity and may have 2 to 3 yr intervals between uniparous births. However, low natality rates and associated low predation rates (Ford \& Reeves 2008 ) result in annual net rates of increase greater than $10 \%$ in humpback whales Megaptera novaengliae and between 6 and $14 \%$ in southern right whales Eubalaena australis (Clapham et al. 1999), although between 3 and $4 \%$ annual population net growth rates are more usual for most whales species.

It appears that today, and likely for the past few decades, the majority of depleted whale stocks are recovering (Aron 1988, Gerber et al. 2000). However, in some cases, although particular stocks or population segments of a species are recovering, other regional stocks of that same species may not be (Clapham et al. 2008). In the case of the bowhead, the North Pacific population was thought to be reduced to between 1000 and 2000 individuals from a pre-industrial population of ca. 22000 , when commercial whaling ceased at the end of the first decade of the 20th century. Recovery was slow initially, and aboriginal hunting continued to remove small numbers of bowheads each year. As the whale population numbers increased, so did the annual removals, so that 50 or $60 \mathrm{yr}$ after commercial whaling ended the aboriginal hunt was annually removing 70 or more bowheads from a population that had recovered to more than 10000; it is currently increasing at a net rate of more than $3 \%$ per year (Gerber et al. 2007).

In the Canadian eastern Arctic, bowheads have shown a similar pattern of recovery, although a smaller initial population (believed to have numbered around
$12000)$ in the mid-19th century was likely reduced to the low hundreds following about $60 \mathrm{yr}$ of intense commercial whaling that ended during the first decade of the 20th century. Although small numbers of removals resulted from continuing community-based whaling, recovery of this severely depleted population was observed from about 40 to $50 \mathrm{yr}$ after commercial whaling ended (Hay et al. 2000). Conservative estimates place the current population at ca. 7300 bowheads (Cosens et al. 2006), which under moderate levels of hunting is predicted to achieve full recovery in the next few decades (Dueck \& Richard 2006). In contrast, a historic population of bowhead whales estimated to have numbered between 25000 and 100000 in the Spitsbergen region was commercially hunted from the 17 th to the end of the 19th century, and is now thought to only number in the low tens. This suggests that no observed recovery of that remnant population has occurred (Clapham et al. 2008). Interestingly, and most would argue appropriately, the IUCN Red List status of bowheads has changed over the past few decades, from 'Endangered' in 1986 to 'Vulnerable' in 1990 to 'Lower Risk (conservation dependent)' in 1996 (and currently) as population recovery has occurred over much of the species range where the net rate of population increase is around $3.2 \%$ per year.

Reliable population information is also available for the California gray whale, where the pre-commercial whaling population was believed to have numbered between 20000 and 25000 before being reduced to a few hundred (Small 1971, Clapham et al. 1999) or a 
Table 4. Major current and/or future threats used to justify Red Listing of commercially hunted whales. Population estimates vary from reasonable certainty (for the common minke) to highly uncertain (for the sperm and sei whales). An extensive web-based search suggested that the sources given in footnotes a to e provided estimates within the range of those available from many available sources. LR/NT: Lower Risk/Near Threatened (close to 'vulnerable'); LR/CD: Lower Risk/Conservation Dependent (subject to a conservation program, the ending of which would qualify the taxon for a Vulnerable, Endangered or Critically Endangered listing)

\begin{tabular}{|c|c|c|c|}
\hline Species & Population estimate & $\begin{array}{l}\text { Listing } \\
\text { category }\end{array}$ & Threat \\
\hline \multirow[t]{2}{*}{$\begin{array}{l}\text { Common minke } \\
\text { Balaenoptera acutorostrata }\end{array}$} & $209800^{a}$ & LR/NT & $\begin{array}{l}\text { Harvesting (hunting/gathering) - food - } \\
\text { subnational/national/regional/ } \\
\text { international trade (past \& ongoing). } \\
\text { Cultural/scientific/leisure activities }\end{array}$ \\
\hline & & & $\begin{array}{l}\text { Accidental mortalities - bycatch - } \\
\text { fisheries-related (ongoing) }\end{array}$ \\
\hline \multirow[t]{2}{*}{$\begin{array}{l}\text { Antarctic minke } \\
\text { Balaenoptera bonaerensis }\end{array}$} & $>600000^{\mathrm{b}}$ & $\mathrm{LR} / \mathrm{CD}$ & $\begin{array}{l}\text { Harvesting (hunting/gathering) - food - } \\
\text { subnational/national/regional/ } \\
\text { international trade (past \& ongoing). } \\
\text { Cultural/scientific/leisure activities }\end{array}$ \\
\hline & & & $\begin{array}{l}\text { Accidental mortalities: bycatch - } \\
\text { fisheries-related (ongoing) }\end{array}$ \\
\hline $\begin{array}{l}\text { Sei whale } \\
\text { Balaenoptera borealis }\end{array}$ & $\begin{array}{l}\text { S. Hemisphere } 24000^{c} \\
\text { N. Atlantic } 10000 \\
\text { N. Pacific } 22000-37000\end{array}$ & $\begin{array}{l}\text { EN } \\
\text { A1abd }\end{array}$ & $\begin{array}{l}\text { Harvesting (hunting/gathering) - food - } \\
\text { regional/international trade (past) }\end{array}$ \\
\hline $\begin{array}{l}\text { Sperm whale } \\
\text { Physeter macrocephalus }\end{array}$ & $\begin{array}{l}200000-1.5 \text { Million }^{\mathrm{d}} \\
350000^{\mathrm{e}}\end{array}$ & $\begin{array}{l}\text { VU } \\
\text { A1bd }\end{array}$ & $\begin{array}{l}\text { Harvesting (hunting/gathering) - food - } \\
\text { regional/international trade (past). } \\
\text { Accidental mortalities: bycatch - } \\
\text { fisheries-related - entanglement (ongoing). } \\
\text { Intrinsic factors: poor recruitment/ } \\
\text { reproduction/regeneration (present, future) - } \\
\text { other (present, future) }\end{array}$ \\
\hline
\end{tabular}

few thousand (Gerber et al. 2000) during historic commercial whaling operations. Ongoing hunting resulted in annual removals of ca. 170 gray whales by commercial and aboriginal whalers until ca. 1990, after which 140 to 150 whales have been removed annually by aboriginal whalers. It appears that full recovery of the population occurred around the year 2000; at this time, the population peaked at around 26600 , followed by natural die-off over the next few years to what appears to be a more sustainable population level (given current conditions) of ca. 23000.

Other whale populations have experienced even greater levels of depletion than the Pacific bowhead and the eastern Pacific gray whale. The most notable example is the northern right whale Eubalaena glacialis, which currently numbers in the low hundreds and is considered the most endangered whale species. It has been suggested that non-recovery may result from difficulty in locating mates or the genetic consequences of small population size (Gerber et al. 2000), or shortage of suitable feeding locations (Moore 2004). Both northern and southern right whales were each reduced to about 350 individuals by over-hunting of a pre-exploitation population believed to number ca. 60000 whales in each case. However, southern right whales have now increased to about 8000 and show high rates of increase in several regions, notably South Africa (6.6\%), Argentina (7.6\%) and off the west coast of Australia (11.7 to $13 \%$ ) (Perry et al. 1999). Other southern right whale stocks are not recovering at such high rates, and the northern right whale population of about 350 animals remains quite static. It has been suggested, on the basis of recent DNA research (Lippsett 2005), that an uncounted population, representing a further 10 to $15 \%$ males, may account for the northern right whales' uneven rate of reproductive success (e.g. 26 calves in 2001, the largest number counted since the 1980s; Pittman 2001). Ship collisions and netentanglements are the main causes of mortality in the nearshore waters where northern right whales occur (Clapham et al. 1999). 
Slow recovery has also been observed in Antarctic stocks of the blue whale Balaenoptera musculus. This southern hemisphere stock feeds almost exclusively on a single prey species (krill Euphausia superba), and its slow rate of recovery may result from unsuccessful competition with other krill-feeding species — including the Antarctic minke whale, crabeater seals Lobodon carcinophagus, leopard seals Hydrurga leptonyx and antarctic fur seals Arctocephalus gazella-all of which experienced significant population increases following the decline in blue whale numbers (Boyce 2000). However, blue whale populations in the North Atlantic and the eastern North Pacific appear to be increasing (Gerber et al. 2000).

\section{MEETING WHALE CONSERVATION GOALS}

Have conservation goals been met? Seeking the answer to this question has policy importance, as mentioned earlier, as well as other practical and ethical considerations that flow from the ongoing contribution of whales to some peoples' nutritional, cultural, and socio-economic needs. Unnecessarily restricting access to these important resources through unwarranted protection raises ethical and legal issues of human rights and distributive justice (Ward 1993). The World Conservation Strategy, Agenda 21, the Convention on Biological Diversity, and policies adopted and actions taken by IUCN all stress the importance of social equity and the sustainable use of natural resources for achieving successful and enduring conservation outcomes (Edwards 1995, Hutton \& LeaderWilliams 2003, Kinne 2006).

Some whale populations may be increasing, and some may not. However, there remains uncertainty about the reliability of historic and current population level estimates (see next paragraphs), making it difficult to decide whether conservation goals have been met in each case. Furthermore, there is very little information allowing a useful understanding of non-anthropogenic marine environmental changes that might influence whale abundance over decadal or centurylong intervals. In addition, the high level of current public interest in whales encourages biologists and managers to be cautious in suggesting that whale recovery has occurred or is underway, unless the evidence for it is quite certain. Currently, a steady stream of reports predicting elevated risks of extinction due to climate warming over the next few decades has caused many scientists to express uncharacteristic certitude when predicting species' increased risk of extinction in the next few decades (IUCN 2007e; however, see cautions in Hilborn 2006, Krebs \& Berteaux 2006, Botkin et al. 2007).
One difficulty associated with assessing recovery of depleted whale populations arises from establishing acceptable estimates of pre-exploitation population levels. The currently accepted method of doing this relies heavily on analysis of whaling ship logbooks and industrial records of barrels of oil and sheets of baleen plates entering the market (Tillman \& Donovan 1983, Smith \& Reeves 2006). However, recent DNA-based research has produced pre-exploitation population estimates many times larger than those obtained through currently accepted log-book and marketreport analyses for whales in the North Atlantic (Roman \& Palumbi 2003) and the North Pacific (Alter et al. 2007). The new estimates were obtained by measuring the diversity of mutations in the DNA of living whales, and comparing these findings to the rate at which such mutations are thought to occur in whales. The results suggested a pre-exploitation North Atlantic humpback whale population of $240000-\mathrm{a}$ large increase over the currently accepted pre-whaling population estimate of 40000 . The North Atlantic fin whale Balaenoptera physalus population, using genetic analytic methods, is 360000 , compared to a currently accepted estimate of between 30000 and 50000 (Roman \& Palumbi 2003).

Geneticists and whale biologists are critical of these new elevated population estimates, noting the untested methodology and a number of questionable assumptions being used (Clarke 2003, Lubick 2003, Mitchell 2004, Palsbøll et al. 2007). For example, genetic diversity is a product of mutations continuously occurring in the aggregate population of all whales of a given species over millions of years of existence (e.g. 6 to 10 million yr for the humpback whale) at unknown rates that might have varied at different periods of evolutionary time in populations whose numbers also varied over those millions of years. In addition, estimates of genetic diversity are complicated and error-prone, such that subtle and small changes in the assumed mutation rates can lead to massive yet spurious changes in the calculated results (Clarke 2003).

\section{ESTABLISHING VALID AND CREDIBLE CONSERVATION GOALS}

Setting conservation goals is more often a question of culture or politics than of science (Gerber et al. 2000, Heazle 2004). If the culturally determined goal is to reestablish marine ecosystems having several hundred thousand more large-bodied whales, this raises serious fisheries management questions in a world that might expect to at least partially meet the future global foodsecurity needs of a growing human population from a diverse array of exploitable marine resources. How- 
ever, a more basic question remains: What is the purpose or ecological justification for seeking to re-create an uncertain hypothetical pre-exploitation population level from centuries earlier when the marine environment at that earlier time (1) no longer exists and can realistically never be reconstituted (even if we knew its composition), and (2) was never anything other than the local marine community existing at a unique, highly dynamic and ever-changing period in time? This improbable and arguably irrelevant exercise seems to provide the rationale for much of what passes for marine mammal conservation orthodoxy today, at least when whales are being discussed. As has been cautioned elsewhere, to manage man-altered ecosystems is a dubious concept because we do not know enough about ecosystem dynamics to safely conduct large-scale experiments in nature (Kinne 2006).

The IUCN Red List is assumed by many interested parties to be authoritative, and the listings are certainly used as such by many, including journalists, editors and various interest groups. However, there is a danger when such information is uncritically used by individuals who either do not understand the significance of, or choose to ignore, such notations as 'out of date' or using 'version 2.3' (i.e. the 1994 listing criteria, replaced in 1996 by new and improved criteria). The 2007 Red List categorizes the fin whale as 'Endangered' and the humpback whale as 'Vulnerable' (using the 1994 listing criteria and out-dated population estimates). The Cetacean Specialist Group very likely has access to updated data that allow reassessment according to current criteria and population numbers, which in the case of the southern hemisphere humpback whales have likely doubled or tripled. Regardless of whether the updated assessments have not been made by the specialists, or not adopted by the wider IUCN process, or just not announced to the public, it is unfortunate, given the advocacy or other political use made of IUCN listings, that posting outdated information fuels conflict in politicized fora where whales or whaling (Aron et al. 2000, ICR 2007), or the conservation of other charismatic species (Lapointe 1997, Webb $\&$ Carrillo 2000) are the focus of discussion.

\section{ACCEPTABLE WHALE POPULATION LEVELS}

Science cannot tell us what is an ecologically appropriate whale (or other species') population size, for science cannot predict with any degree of certainty or accuracy what the effect on marine biodiversity would be if large increases in whale numbers occurred (see Beninca et al. 2008). Today, science-based fisheries management stresses an ecosystem, or multi-species, approach, as variously endorsed in Agenda 21, the
Convention on Biological Diversity, the UN Food and Agricultural Organization (FAO) and such sciencebased organizations as the North Atlantic Marine Mammal Commission (NAMMCO), the Pacific International Council for the Exploration of the Sea (PICES) and the Indian Ocean Tuna Commission among others (Iino \& Goodman 2003). Whales, being large-bodied top predators, are widely recognized as a management consideration in some heavily fished regions today. For example, in northeast US coastal waters, cetaceans are significant predators, removing 3.5 to 6.6 times the quantity of fish taken in commercial fishery catches (Kenney et al. 1997). In the Pacific Ocean, marine mammals annually remove about 3 times the quantity of fish taken by commercial fishers (Trites et al. 1997). The same concerns about cetacean predation exist in the North Atlantic fisheries (Vikingsson \& Kapel 2000) and elsewhere (Iino \& Goodman 2003) where whales are abundant or increasing in numbers.

Although conservation today is concerned with maintaining the integrity of biological communities and sustaining the livelihoods of dependent resource users, when it comes to highly politicized charismatic species this contemporary understanding of conservation seems not to apply, and the debate is much more about special interests and values than science (Butterworth 1992, Mrosovsky 2000, Heazle 2004, Gerber et al. 2007).

\section{SAFEGUARDING WHALE STOCKS}

Influenced by theoretical formulations (Clarke 1976), many believed that it was impossible for commercial whale fisheries to ever be sustainable (Small 1971, Myers 1979). However, bioeconomic analysis (Conrad \& Bjørndal 1993) and better empirically based understanding of small-scale whaling practices and common-property issues (see 'Sustainability of whale fishing') appear to contradict this belief. Indeed, the scientific committees of the International Whaling Commission (IWC) and the NAMMCO are among the scientific bodies agreeing that whale stocks numbering several thousand or more can sustain a regulated commercial whale fishery. An annual take of $2 \%$ of a conservative population estimate is considered sustainable (Gerber et al. 2000), and the IWC has approved a risk-averse management procedure that conservatively sanctions catch levels at one-half of $1 \%$ of the estimated whale stock size. This IWC management scheme, the so-called Revised Management Procedure (RMP), was exhaustively tested by the IWC Scientific Committee and is considered highly conservative in comparison with all other fishery and wildlife regimes (Gambell 1995). This adaptive man- 
agement regime, successfully used in the Norwegian minke whale fishery since 1993, accommodates all future oceanic environmental changes, including climate change and pollution, resulting from known and unknown natural and anthropogenic events. Some regional whale populations that were reduced to very low levels, and in some cases have not shown recovery, are afforded complete protection from whaling (i.e. zero quotas) under current international whaling management procedures.

The global demand for whale products today is small, and evidence suggests that it is unlikely to grow (Aron et al. 2000, Greenpeace 2007). In 2007, Iceland announced that it was suspending its limited commercial whaling operations due to lack of demand for whale products at home and abroad (Clover 2007). Even in Japan and Norway (the 2 other, and much larger, commercial-whaling nations), about $40 \%$ of people considered whalemeat an unacceptable food item more than a decade ago (Freeman \& Kellert 1994), a level of unacceptability likely to increase as internationalization continues to transform the consumer tastes of their growing urban populations.

International trade in whale products effectively ended in 1989, and no significant incidents of poaching have been discovered since the trade ban was imposed. Reports of irregular incidents, involving small amounts of allegedly unauthorized meat (Baker \& Palumbi 1994) have subsequently been accounted for by products lawfully derived from whale strandings, fishery bycatch, and then-remaining stockpiles of legally imported whalemeat (Mills et al. 1997, Phipps et al. 1998). It appears that if illegal taking of whales occurs, it is neither extensive nor does it involve critically threatened whale populations (Clapham et al. 1999).

International efforts to control unsustainable whaling practices before and immediately following World War II were ineffective, as public indifference in those years resulted in an absence of political will to prevent serious over-exploitation of whale stocks by economically and politically influential large-scale whaling industries. However, today, those industries no longer exist, and there is no unmet consumer demand to justify replacing them. In addition, there exists widespread public and government concern about whales and whaling, and many well-funded non-government organizations are committed to keeping governments vigilant.

\section{SUSTAINABILITY OF WHALE FISHING}

Continuation of community-based whale fisheries that have persisted over centuries suggests that sustainability of whaling can be attained and maintained, although some have argued that such past examples succeeded only because human population size was small and primitive hunting equipment was being used. However, early Basque, Dutch, Scottish, American and other nations' whalers depleted many whale stocks in a few decades using simple hand-held weapons from the 17th century onwards (Ellis 1991), suggesting that even simple technology can, in the face of a large global market demand, result in serious over-exploitation. Despite the over-exploitation that characterized industrial whaling in the past, sustainable whaling co-existed with unsustainable whaling for centuries, during times when commercial trade in whale products flourished, together with subsistence practices (Marquardt \& Caulfield 1996, Freeman 2001).

Advanced technologies in use today are important for ensuring that whaling is sustainable, more humane and efficient. For example, in regard to monitoring whaling operations for compliance with quotas for example, DNA registers of landed whale products, international observer schemes, and remote sensing of whaling activities (Øen 2005) provide effective means to deter and detect non-compliance.

Some of the critical features of community-based whaling associated with sustainability include limiting whaling access to members of socially defined groups dependent upon that resource stock. Whales and whaling often provide multiple benefits to societies depending upon those resources, benefits that variously possess significant social, symbolic, ceremonial, dietary, economic, historical, spiritual and psychic importance. Related to this, whaling knowledge and skills, when transmitted inter-generationally, serve to reinforce social solidarity and compliance with prevailing societal norms that favour the continuing and respectful hunting and use of these valued food resources (Young et al. 1994). Now that export markets no longer exist for whale products, commercial whaling is to a very great extent practised by individuals living in small communities where whaling has been an honoured profession for generations. It is in such communities that whaling traditions and identity remain matters of intense personal and collective pride, and consequent social sanctions remain effective in ensuring compliance with best practices (Kalland \& Moeran 1992, Aron et al. 2000).

\section{DISCUSSION AND CONCLUSIONS}

Many of the scientific uncertainties that justified a pause in commercial whaling in the 1980s have, for the species of interest to commercial whalers, been removed due to increased attention given to whale 
research by the whaling nations and the Scientific Committee of the IWC. Scientists have developed rigorous sighting-survey methods, robust statistically reliable methods for obtaining abundance estimates of whale stocks, and a safe and simple method of setting catch limits; these limits allow stable and continuing yields, while ensuring that depleted stocks continue to recover in the face of changing environmental conditions (Gambell 2003).

It appears that the resilience of many whale stocks and the time elapsed since the collapse of the global market for whale products have together removed what was earlier considered the major threat to whales. The IWC has endorsed its Scientific Committee's risk-averse and highly conservative procedure for setting sustainable catch levels, and these measures, together with an ongoing decline in market demand, allow a very high level of assurance that fear of a return to unsustainable whaling is unjustified. Nevertheless, the major fears that prompted a pause in commercial whaling 20 yr ago linger (see Table 4), and in regard to listing of whales 'the difficulty of balancing the reality of a decline from previous global abundance with present low probability of extinction is a problem that the IUCN criteria have not yet solved' (Ross 2000, p. 28; see also Webb \& Carrillo 2000, Mrosovsky 2004). Although the 1994 changes to the Red List criteria refined the assessment process, the current detailed criteria likely cannot overcome problems originating not with the stated criteria per se, but rather with the manner in which these objective criteria may be subjectively interpreted and applied. It may also be appropriate to ask whether the criteria used to list terrestrial species are, in every case appropriate when listing wide-ranging, long-lived and abundant oceanic species. Just as small island endemic species are much more vulnerable to extinction than are wideranging species occupying continental land masses, so too may oceanic species be that much, or more, secure.

Today, there is concern that whales, together with many other taxa worldwide, are beginning to face grave threats that may be far greater than those posed by the current or expected future demand for their products. The new threats are associated with predicted effects of climate change on global biodiversity. Certainly, animal and plant distribution patterns and population numbers will change in the future, as they have in the past, but as others have noted: 'recent ecological and genetic research, along with specific problems with present forecasting methods, lead us to believe that current projections of extinction rates are overestimates' (Botkin et al. 2007, p. 228; see also Berteaux et al. 2006). Science-based predictions require use of a rigorous methodology when carried out by forecasting specialists (Green \& Armstrong
2007, Armstrong et al. 2008), but the appropriate forecasting methodology is rarely (if ever) applied by biologists who nevertheless make confident and dire predictions about the effect of environmental changes on species' survival prospects (Ehrlich \& Ehrlich 1975, Myers 1983, Amstrup et al. 2007).

Some biologists express the view that climate changes in the 21 st century will, due to the rapidity of the predicted change, be quite unlike warming episodes in the past, while others note that the predicted changes are no greater nor rapid than most extant species have experienced in the past (Botkin et al. 2007). Whales are highly mobile oceanic animals, without the geographic barriers or habitat fragmentation or loss commonly faced by many terrestrial species. The history of whaling suggests that major compositional changes to whale populations and their associated biotic communities have occurred (Gambell 2003) and very rapidly (over mere decades), suggesting that whale species' resilience has allowed severely depleted populations to nevertheless recover in a relatively short time (in relation to whale longevity). In those cases where recovery has not appeared to have occurred, it is possible that recovery is occurring very slowly (e.g. Hay et al. 2000, Heide-Jorgensen et al. 2007) or that extirpation or displacement of that population will prove to be long term or permanent for environmental or biological reasons (Clapham et al. 2008). Arguably, population recovery or persistence has been an outcome equal to or more prevalent than nonrecovery among whale stocks.

When considering the almost identical Red Listing of the ubiquitous sperm whale and the localized Amazon river dolphin, one is reminded of the intense attraction that the general public and many biologists who study whales feel toward whales and dolphins; in that regard, the sperm whale is particularly iconic. Obtaining information needed to properly list whales - and more importantly, to manage them - is at best an inexact science. It appears that for those whose passion for whales is great, the perception of an elevated risk associated with removing even one whale out of a robust population may trigger an aversion that can be just as intense as removing one whale out of a highly depleted remnant population. For those individuals, protection and population recovery may be more a moral than a technical and scientific matter. However, assessing candidate species for Red Listing does not explicitly call for any moral assessment to be made in the assessment process, although some biologists may consider use of the 'precautionary principle' as justified moral (as opposed to evidence-based) grounds when empirical data are lacking.

The precautionary principle is an approach to responding to uncertainty in the face of risks. It 
involves 'acting to avoid serious or irreversible potential harm, despite lack of scientific certainty as to the likelihood, magnitude, or causation of that harm' (www.pprinciple.net/the_precautionary_principle.html) It appears that this principle can be applied in the absence of sound scientific information to support a position regarding the degree of real or perceived extinction threat a species faces. The dangers of such actions in international fora such as CITES, where delegates may have little knowledge of the animals or plants being considered for listing, is that invoking the precautionary principle implies that a significant risk of endangerment exists, thus triggering actions that overrule the potential benefits offered by another important conservation tool, namely sustainable resource use (IUCN 2000, Hutton \& Leader-Williams 2003).

What, then, of the precautionary principle that appears to have been invoked in order to justify such assessments as may have occurred in the sperm whale/Amazon river dolphin cases described earlier? Perhaps we should more fully recognize the subjectivity that enters the Red Listing process when reliable scientific data do not exist, especially in regard to assessments involving charismatic or iconic taxa. Or perhaps, heed the recent observation that 'generally the precautionary principle is best left in international conventions' (Milner-Gulland \& Rowcliffe 2007, quoted in Sharp 2007, p. 29) and that over-inflating the risk of extinction 'should not be assigned to species that are abundant and widespread, with no known scenarios that could lead to global extinction, no matter how compelling the case for public sympathy may be' (Webb \& Carillo 2000, p. 17).

Acknowledgements. The author acknowledges helpful comments provided by 2 anonymous reviewers, suggestions and editorial guidance by Drs. Brendan Godley and Matthew Godfrey, technical assistance from Ms. Cindy Mason and research funding from the National Centres of Excellence ArcticNet Program.

\section{LITERATURE CITED}

Alter SE, Rynes E, Palumbi SR (2007) DNA evidence for historic population size and past ecosystem impacts on gray whales. Proc Natl Acad Sci USA 104:15162-15167

Amstrup SC, Marcot BG, Douglas DC (2007) Forecasting the range-wide status of polar bears at selected times in the 21st century. USGS Science Strategy to Support US Fish and Wildlife Service Polar Bear Listing Decision. Administrative Report, US Geological Survey, Reston, VA

Armstrong JS, Green KC, Soon W (2008) Polar bear population forecasts: a public-policy forecasting audit. Working Paper Version 55: February 21, 2008. Available online at: www.forecastingprinciples.com/Public_Policy/PolBears.pdf Aron W (1988) The commons revisited: thoughts on marine mammal management. Coast Manag 16:99-110

Aron W, Burke W, Freeman MMR (2000) The whaling issue. Mar Policy 24:179-191

> Baker CS, Palumbi SR (1994) Which whales are hunted? a molecular genetic approach to monitoring whaling. Science 265:1538-1539

> Beninca E, Huisman J, Heerkloss R, Jöhnk KD and others (2008) Chaos in a long-term experiment with a plankton community. Nature 451:822-825

Berteaux D, Humphries MM, Krebs CJ, Lima M and others (2006) Constraints to projecting the effects of climate change on mammals. Clim Res 32:151-158

Botkin DB, Saxe H, Araúja MB, Betts R and others (2007) Forecasting the effects of global warming on biodiversity. BioScience 57:227-236

Boyce M (2000) Whaling models for cetacean conservation. In: Ferson S, Burgmann M (eds) Quantitative methods for conservation biology. Springer, New York, p 109-126

Brownell RL Jr, Ralls K, Perrin WF (1989) The plight of the 'forgotten' whales. Oceanus 32:5-11

Butterworth DS (1992) Science and sentimentality. Nature 357:532-534

Clapham PJ, Link J (2006) Whales, whaling and ecosystems in the North Atlantic. In: Estes J (ed) Whales, whaling and ecosystems. University of California Press, Berkeley CA, p 241-250

Clapham PJ, Young SB, Brownell RL Jr (1999) Baleen whales: conservation issues and the status of the most endangered populations. Mammal Rev 29:37-62

Clapham PJ, Aguilar A, Hatch LT (2008) Determining spatial and temporal scales for management: lessons from whaling. Mar Mamm Sci 24:183-201

Clarke CW (1976) Mathematical bioeconomics: the optimal management of renewable resources. Wiley, New York

Clarke T (2003) Whale numbers disputed: pre-whaling population estimates upset conservationists. Nature. Available online at: www.nature.com/news2003/030725/full/ news030721-12.html

Clover C (2007) Iceland ends whaling due to lack of demand. Telegraph.co.uk, August 242007 posting available online at: www.telegraph.co.uk/earth/main.jhtml?xml=/earth/ 2007/08/24/eawhale124.xml

Conrad J, Bjørndal T (1993) On the resumption of commercial whaling: the case of the minke whale in the northeast Atlantic. Arctic 46:164-171

Cosens S, Cleator H, Richard P (2006) Numbers of bowhead whales (Balaena mysticetus) in the eastern Canadian Arctic, based on aerial surveys in August 2002, 2003 and 2004. Can Sci Advis Secretariat Res Doc 2006-052. Fisheries and Oceans Canada, Ottawa

Dueck LP, Richard P (2006) Assessment of the recovery potential of the eastern arctic bowhead whale population by deterministic projections with a modified logistic growth model. Can Sci Advis Secretariat Res Doc 2006-053. Fisheries and Oceans Canada, Ottawa

Edwards SR (1995) Conserving biodiversity: resources for our future. In: Bailey R (ed) The true state of the planet. Free Press, New York, p 211-265

Ehrlich PH, Ehrlich A (1975) Extinction: the causes and consequences of the disappearance of species. Random House, New York

Ellis R (1991) Men and whales. Knopf, New York

$>$ Ford JKB, Reeves RR (2008) Fight or flight: antipredator strategies of baleen whales. Mammal Rev 38:50-86

Freeman MMR (2001) Is money the root of the problem? Cultural conflict in the IWC. In: Friedheim, RL (ed) Towards a sustainable whaling regime. University of Washington 
Press, Seattle, WA and CCI Press, Edmonton, AB, p 123-146

Freeman MMR, Kellert SR (1994) International attitudes to whales, whaling and the use of whale products: a sixcountry survey. In: Freeman MMR, Kreuter UP (eds) Elephants and whales: resources for whom? Gordon and Breach, Basel, p 293-315

Gambell R (1995) Management of whaling in coastal communities. In: Blix AS, Walløe L, Ulltang O (eds) Whales, seals, fish and man. Elsevier, Amsterdam, p 699-708

Gambell R (2003) I am here, where should I be? In: Burns WCG, Gillespie A (eds) The future of cetaceans in a changing world. Transnational Publishers, Ardsley, NY

> Gerber L, DeMaster D, Roberts S (2000) Measuring success in conservation. Assessing efforts to restore populations of marine mammals is partly a matter of epistemology: How do you know when enough is enough? Am Sci 88: 316-324

Gerber LR, Keller AC, DeMaster DP (2007) Ten thousand and increasing: Is the western Arctic population of bowhead whale endangered? Biol Conserv 137:577-583

Green KC, Armstrong JS (2007) Global warming: forecasts by scientists versus scientific forecasts. Energy Environ 18:997-1021

Greenpeace (2007) Whale meat: it's what's NOT for dinner. Whaling 101 webpage. Greenpeace, available online at: www.greenpeace.org/usa/campaigns/oceans/whaledefenders/whaling-101

Hay K, Aglukark D, Igutsiaq J, Ikkidluak J, Mike M (2000) Final report of the Inuit bowhead knowledge study. Nunavut Wildlife Management Board, Iqaluit, Nunavut. Available online at: www.nwmb.com/english/resources/ Bowheadreport.pdf

Heazle M (2004) Scientific uncertainty and the International Whaling Commission: an alternative perspective on the use of science in policy making. Mar Policy 28: 361-374

Heide-Jørgensen MP, Laidre K, Borchers D, Samarra F, Stern $H$ (2007) Increasing abundance of bowhead whales in West Greenland. Biol Lett 3:577-580

Hilborn R (2006) Faith-based fisheries. Fisheries 31:554-555. Available online at: http://www.fisheries.org/afs/docs/ fisheries/fisheries_3111.pdf

Hutton JM, Leader-Williams N (2003) Sustainable use and incentive-driven conservation: realigning human and conservation interests. Oryx 37:215-226

ICR (Institute of Cetacean Research) (2007) Journalists and editors misinforming the public-again. November 28, 2008 Press release, The Institute of Cetacean Research, Tokyo. Available online at: http://icrwhale.org/ 0711128Release.htm

Iino Y, Goodman D (2003) Japan's position in the International Whaling Commission. In: Burns WCG, Gillespie A (eds) The future of cetaceans in a changing world. Transnational Publishers, Ardsley, NY, p 3-32

IUCN (International Union for Conservation of Nature and Natural Resources) (2000) IUCN policy statement on sustainable use of wild living resources. Available online at: www.iucn.org/themes/ssc/susg/docs/valeurs_annex2.pdf

IUCN (2007a) The IUCN Red List of threatened species. Available online at: www.iucnredlist.org

IUCN (2007b) IUCN Red List of threatened species: Physeter macrocephalus. Available online at: www.iucnredlist.org/ search/details.php/41755/summ

IUCN $(2007 \mathrm{c})$ Guidelines for using the IUCN Red List categories and criteria. Version 6.2. Available online at: http://intranet.iucn.org/webfiles/doc/SSC/RedList/ RedListGuidelines. pdf
IUCN (2007d) IUCN Red List of threatened species: Balaenoptera bonaerensis. Available online at: www. iucnredlist.org/search/details.php/2480/summ

IUCN (2007e) Extinction crisis escalates: Red List shows apes, corals, vultures, dolphins all in danger. Available online at: www.iucn.org/en/news/archive/2007/09/12_pr_redlist.htm

Kalland A, Moeran B (1992) Japanese whaling: end of an era? Curzon Press, London

Kenney RD, Scott GP, Thompson TJ, Winn HE (1997) Estimates of prey consumption and trophic impacts of cetaceans in the USA northwest continental shelf ecosystem. J Northwest Atl Fish Sci 22:155-171

$>$ Kinne O (2006) Protecting nature. Endang Species Res 1:1-2

Klinowska M (1991) Dolphins, porpoises and whales of the world. The IUCN Red Data book. International Union for Conservation of Nature and Natural Resources, Gland

Krebs CJ, Berteaux B (2006) Problems and pitfalls in relating climate variability to population dynamics. Clim Res 32:143-149

Lapointe E (1997) No red alert over conservation Red Listings. Nature 389:904

Lippsett L (2005) Diving into the right whale gene pool. Oceanus 44:18-19

Lubick N (2003) New count of old whales adds up to a big debate. Science 301:451

Marquardt O, Caulfield RA (1996) Development of west Greenland markets for country food since the 18th century. Arctic 49:107-119

Martin AR (1990) Whales and dolphins. Salamander, London

Mills J, Ishihara A, Sakaguchi I, Kang S, Parry-Jones R, Phipps M (1997) Whale meat trade in east Asia: a review of the markets in 1997. TRAFFIC International, Cambridge

Milner-Gulland EJ, Rowcliffe JM (2007) Conservation and sustainable use: a handbook of techniques. Oxford University Press, Oxford

Mitchell ED (2004) Counting whales in the North Atlantic. Science 303:39

Moore M (2004) Whither the North Atlantic right whale? Oceanus 43:1-5

Mrosovsky N (2000) Sustainable use of hawksbill turtles: contemporary issues in conservation. Key Centre for Tropical Wildlife Management, Darwin

Mrosovsky N (2004) Predicting extinction: fundamental flaws in the IUCN's Red List system exemplified by the case of sea turtles. Available online at: http://members.seaturtle. org/mrosovsky/

Myers N (1979) The sinking ark: a new look at the problems of disappearing species. Pergamon, Oxford

Myers N (1983) A wealth of species. Westview Press, Boulder, $\mathrm{CO}$

Øen EO (2005) Electronic monitoring of Norwegian minke whaling. High North Alliance Fact Sheet, Reine. Available online at: www.highnorth.no/Library/Hunts/ Norway/el-mo-of.htm

Palsbøll PJ, Bérubé M Larsen, F (2007) Could genetic diversity in eastern North Pacific gray whales reflect global historic abundance? Proc Natl Acad Sci 104(52) Available online at: www.pnas.org/cgi/content/full/104/52/E2

Perry S, DeMaster DP, Silber G (1999) The right whales. Mark Sci 61:7-23

Phipps M, Ishihara A, Kanda N, Suzuki H (1998) A preliminary report on DNA sequence analysis of whale meat and whale meat products collected in Japan. TRAFFIC Bulletin 17:91-94

Pittman C (2001) Baby boom at sea. St. Petersburg Times, March 20, 2001. Available online at: www.sptimes. 
com/News/032001/State/Baby_boom_at_sea_.shtml

Roman J, Palumbi SR (2003) Whales before whaling in the North Atlantic. Science 301:508-510

Ross JP (2000) Book reviews. Mar Turtle Newsl 88:28-29

Sharp R (2007) Book review: Conservation and sustainable use: a handbook of techniques. Sustainable, December 2007:28-29. Available online at: http://intranet.iucn.org/ webfiles/doc $\backslash S S C \backslash G e n \_d o c s \backslash S u s t a i n a b l e D e c e m b e r 2007$. pdf

Small GL (1971) The blue whale. Columbia University Press, New York

Smith TD, Reeves RR (2006) Pre-20th century whaling: implications for management in the 21st century. In: Ringstad, JE (ed) Whaling and history. II. Kommandør Chr. Christensen Whaling Museum, Sandefjord, p 119-134

Tillman MF, Donovan GP (eds) (1983) Special issue on historical whaling records. IWC Special Issue 5, International Whaling Commission, Cambridge

Trites AW, Christensen V, Pauly D (1997) Competition between fisheries and marine mammals for prey and primary production in the Pacific Ocean. J Northwest Atl Fish Sci

Editorial responsibility: Matthew Godfrey,

Beaufort, North Carolina, USA
22:173-187

Turvey ST, Pitman RL, Taylor BL, Barlow J and others (2007) First human-caused extinction of a cetacean species? Biol Lett 3:537-540

Tyack PH (1989) Let's have less public relations and more ecology. Oceanus 32:103-108

Vikingsson G, Kapel FO (eds) (2000) Minke whales, harp and hooded seals: major predators in the North Atlantic ecosystem. Sci Publ 2, North Atlantic Marine Mammal Commission, Tromsø

Ward E (1993) Indigenous peoples between human rights and environmental protection - based on an empirical study of Greenland. Danish Centre for Human Rights, Copenhagen

Webb JWW, Carrillo EC (2000) Risk of extinction and categories of endangerment: perspectives from long-lived reptiles. Popul Ecol 42:11-17

> Young OR, Freeman MMR, Osherenko G, Andersen RR and others (1994) Subsistence, sustainability and sea mammals: reconstructing the international whaling regime. Ocean Coast Manag 23:117-127

Submitted: December 11, 2007; Accepted: April 30, 2008 Proofs received from author(s): August 8, 2008 